Wioleta Wasil

\title{
Ocena propozycji zmiany ustawy - Kodeks karny w zakresie penalizacji czynów polegających na umieszczaniu w miejscu publicznym do tego nieprzeznaczonym podpisu, rysunku lub napisu bez zgody zarządzającego tym miejscem ${ }^{1}$
}

Assessment of the proposed amendment on the Penal Code concerning penalisation of the acts of placing signature, drawing or inscription in a public place not designated for this purpose and without approval of managed person (WAP-135/18): The amendment proposed in the petition aims to improve the efficiency of investigation and prosecution of persons who committed an act of vandalism by illegally placing graffiti in a public sphere. In the author's opinion adding a new article to the Penal Code is not necessary. A modification of current provisions, e.g. by increasing sanctions provided in the Misdemeanours Code, would be a more appropriate way to achieve promoter's goals.

Keywords: Penal Code, petition, misdemeanours

Słowa kluczowe: Kodeks karny, petycja, wykroczenia

Doktorant na Wydziale Prawa Kanonicznego UKSW, ekspert ds. oceny skutków regulacji BAS; wioleta.wasil@sejm.gov.pl.

\section{Treść i cel petycji}

Przedmiotem petycji nr 145-311/17 jest żądanie nowelizacji ustawy z 6 czerwca 1997 r. - Kodeks karny (t.j. Dz.U. 2017, poz. 2204; dalej: k.k.) w zakresie penalizacji czynów polegających na umieszczaniu w miejscu publicznym do tego nieprzeznaczonym podpisu rysunku lub napisu bez zgody zarządzającego tym miejsce, powodując straty większe niż 500 zł. Postulowana zmiana ma na celu zwiększenie skuteczności ścigania i karania osób, które dopuściły się jednego z przejawów wandalizmu, jakim jest nielegalne umieszczanie graffiti w przestrzeni publicznej.

Opinia sporządzona 16 lutego 2018 r. na zlecenie przewodniczącego Komisji do Spraw Petycji; BAS-WAP 135/18. 
Opiniowanej petycji towarzyszy propozycja legislacyjna nowelizacji Kodeksu karnego w następującym brzmieniu:

„Ustawa z dnia ... r. o zmianie ustawy - Kodeks karny

Art. 1. W Ustawie z dnia 6 czerwca 1997 r. - Kodeks karny (Dz.U. 1997 nr 88 poz. 553, ze zm.) po art. 288 wprowadza się artykuł 288a w brzmieniu:

Art. $288 a$

$\$ 1$. Kto umieszcza w miejscu publicznym do tego nieprzeznaczonym podpis, rysunek lub napis bez zgody zarzadzającego tym miejscem, powodujac straty większe niż 500 złotych podlega grzywnie, karze ograniczenia wolności albo pozbawienia wolności do lat 5.

$\$ 2$. W razie skazania za przestępstwo określone $w \$ 1$ sąd orzeka przepadek przedmiotów, służacych lub przeznaczonych do popelnienia przestępstwa, choćby nie stanowiły własności sprawcy oraz nawiązkę.

\$3. W razie popetnienia czynu określonego $w \$ 1$, jeżeli istnieje taka możliwość orzeka się obowiązek przywrócenia do stanu poprzedniego.

Art. 2. Ustawa wchodzi w życie po upływie 14 dni od dnia ogłoszenia”.

\section{Czy petycja mieści się w zakresie zadań i kompetencji adresata petycji (art. 2 ust. 3 ustawy o petycjach)?}

Petycja dotyczy zmiany ustawy przez Sejm. Zgodnie z art. 95 ust. 1 Konstytucji RP władzę ustawodawczą w Rzeczypospolitej Polskiej sprawują Sejm i Senat. Natomiast stosownie do art. 118 ust. 1 Konstytucji RP inicjatywa ustawodawcza przysługuje m.in. posłom. Artykuł 32 ust. 2 regulaminu Sejmu, w związku z art. 112 Konstytucji RP, precyzuje, że poselskie projekty ustaw mogą być wnoszone przez komisje sejmowe lub grupę co najmniej 15 posłów podpisujących projekt.

Uwzględniając powyższe, należy uznać, że petycja mieści się w zakresie zadań i kompetencji Sejmu.

\section{Wymogi formalne (art. 4 ust. 1 i 2 ustawy o petycjach)}

Petycja spełnia wymogi formalne określone w art. 4 ust. 1 i 2 ustawy o petycjach.

\section{Kwestie, które ekspert uznaje za istotne w związku z petycją}

Problematyka petycji dotyczy zjawiska nielegalnego graffiti. Zgodnie z obowiązującym stanem prawnym sprawcom wykonującym je w niewyznaczonym do tego miejscu grozi odpowiedzialność za dwa rodzaje czynów. Mogą oni odpowiadać za zniszczenie, uszkodzenie cudzego mienia bądź uczynienia go niezdatnym do 
użytku (art. 288 k.k. i art. 124 ustawy z 20 maja 1974 r. - Kodeks wykroczeń, t.j. Dz.U. 2015, poz. 1094; dalej: k.w.) lub za umieszczenie napisu lub rysunku w miejscu publicznym bez zgody zarządzającego tym miejscem (art. 63a k.w.). Mimo istniejącego kryterium rozgraniczenia obu kategorii zachowań, jakim jest dobro prawne (cudze mienie lub porządek publiczny), kwalifikacja danego czynu może budzić wątpliwości.

Artykuł 288 k.k. jest elementem regulacji prawnych służących zwalczaniu zjawiska wandalizmu, który polega na umyślnym niszczeniu lub uszkodzeniu cudzego mienia, zazwyczaj dokonywane bez powodu. Omawiany czyn należy do kategorii czynów przepołowionych, co w tym wypadku oznacza, że jeżeli szkoda majątkowa (tj. suma damnum emergens i lucrum cessans) spowodowana tym czynem nie przekracza 1/4 minimalnego wynagrodzenia, stanowi on wykroczenie z art. 124 k.w. Strona przedmiotowa art. 288 k.k. oraz art. 124 k.w. składa się z trzech znamion, jednym z nich jest: „niszczenie”, które definiowane jest jako jej unicestwienie i pozbawienie zniszczonej rzeczy dotychczasowej wartości, drugie znamię stanowi „uszkadzanie”, a więc spowodowanie zmian w materii rzeczy, która może być dalej używana, ale wymaga naprawienia. W praktyce wątpliwe jest, które zachowanie można uznać za „uszkodzenie rzeczy”: nielegalne umieszczenie napisów lub rysunków na szybie sklepu czy to samo działanie wykonane na murze budynku². Zgodnie z uchwałą Sądu Najwyższego z 13 marca 1984 r., sygn. akt VI KZP 48/83: Umieszczenie napisu lub rysunku w miejscu do tego nie wyznaczonym może stanowić „uszkodzenie mienia” w rozumieniu art. 212 k.k. [obecnie art. 288 k.k. - dopisek W.W.] (albo w zależności od wysokości szkody - wykroczenie $z$ art. 124 k.w.) tylko wówczas, gdy w wyniku tego działania nastąpiło pomniejszenie wartości materialnej lub użytkowej budynku, obiektu lub innej rzeczy w takim stopniu, że do usunięcia tego uszkodzenia konieczne jest naruszenie substancji. W innym przypadku takie działanie stanowić może wykroczenie określone w art. 63a k.w. Z naruszeniem substancji budynku lub innej rzeczy mamy do czynienia, kiedy do usunięcia (ponieważ trudno sobie wyobrazić naruszenie substancji rzeczy przez samo uczynienie na niej napisu lub rysunku3 ${ }^{3}$ ) uszkodzenia konieczna jest (przykładowo) wymiana szyb i fragmentu ściany budynku ${ }^{4}$ Zachowanie sprawcy polegające na umieszczeniu napisu lub rysunku na ścianie budynku nie będzie mogło zostać ocenione jako uszkodzenie cudzej rzeczy, jeżeli do usunięcia wystarczające będzie jego wyczyszczenie za pomocą odpowiednich rozpuszczalników ${ }^{5}$. Trzecim elementem strony przedmiotowej jest zachowanie polegające na uczynieniu rzeczy niezdatną do użytku. Zachowanie to uniemożliwia wykorzystywanie rzeczy

2 L. Wilk [w:] Kodeks karny. Część szczególna, t. II, Komentarz do artykułów 222-316, red. M. Królikowski, R. Zawłocki, 2017, Legalis.

3 M. Kulik, Z prawnokarnej problematyki graffiti, „Prokuratura i prawo” 2001, nr 2, s. 814.

4 Wyrok SN z 22 sierpnia 2002 r., sygn. akt V KKN 362/01.

5 P. Gensikowski [w:] Kodeks wykroczeń. Komentarz, red. P. Daniluk, 2016, Legalis. 
zgodnie z jej przeznaczeniem, co może nastąpić przy braku naruszenia substancji. Rzecz może zostać uznana za niezdatną do użytku zarówno w sytuacji, gdy nie istnieją możliwości przywrócenia jej do pierwotnych właściwości, jak i wtedy, gdy takie możliwości są, wymagają one jednak sił i nakładów finansowych ${ }^{6}$.

Praktyka orzecznicza wskazuje, że wypadki, kiedy uczynienie napisu lub rysunku na cudzej rzeczy powodować będą odpowiedzialność z art. 124 k.w. lub art. 288 k.k., należą do rzadkości. Regułą jest odpowiedzialność za czyn z art. 63a k.w. Jest to wykroczenie polegające na umieszczeniu w miejscu publicznym ogłoszenia, plakatu, afisza, apelu, ulotki, napisu lub rysunku albo wystawieniu tychże na widok publiczny w innym miejscu bez zgody zarządzającego tym miejscem ${ }^{7}$. Przedmiotem ochrony tego przepisu jest porządek publiczny - nie stanowi to ograniczenia dla penalizacji większości graffiti, ponieważ są one niemal zawsze wykonywane w miejscach dostępnych dla nieograniczonej ilości osób ${ }^{8}$. Wykroczenie może zostać popełnione zarówno umyślnie (w obu postaciach zamiaru), jak i nieumyślnie. Strona podmiotowa ma powszechny charakter. Może je popełnić każdy. Wyjątkiem jest osoba zarządzająca danym miejscem. Za popełnione wykroczenie nie może odpowiadać nieletni, ponieważ art. $1 \$ 2$ pkt 2 lit. b ustawy z 26 października 1982 r. o postępowaniu w sprawach nieletnich (Dz.U. 2017, poz. 773) nie zalicza go do czynów karalnych. Sprawca wykroczenia podlega karze ograniczenia wolności albo grzywny. Ustawodawca przewidział także możliwość orzeczenia środków karnych w postaci przedmiotów stanowiących przedmiot wykroczenia, nawiązki do 1500 zł lub obowiązku przywrócenia do stanu poprzedniego. Możliwe jest orzeczenie wskazanych środków kumulatywnie lub każdego z nich niezależnie. Nie ma podstaw, aby twierdzić, że między wykroczeniem z 63a k.w. a art. 124 k.w. zachodzi zbieg pozorny. Doktryna jednoznacznie wskazuje, że wykonanie graffiti, co do zasady rodzi odpowiedzialność za wykroczenie stypizowane w art. 63a k.w., ponieważ graffiti z reguły nie narusza substancji rzeczy ${ }^{9}$.

Podmiot wnoszący petycje w uzasadnieniu wskazuje na nieskuteczność ścigania sprawców nielegalnego graffiti, które zmniejsza walor estetyczny przestrzeni publicznej, powodując znaczne szkody. Odpowiedzialnością za to obarcza złe ustawodawstwo, które według niego wymaga zmiany. Dokonując oceny przedmiotu petycji, nasuwa się pewna wątpliwość, bowiem, jeśli regułą jest, że zachowanie polegające na umieszczeniu napisu lub rysunku w miejscu do tego niewyznaczonym podlega dyspozycji art. 63a k.w., to czy w każdym wypadku tego wykroczenia przewidziana przepisem sankcja jest na tyle wystarczająca, że spełnia swoje funkcje (represyjną i resocjalizacyjną). W ocenie autora petycji stosowany w odniesieniu do sprawców nielegalnego graffiti reżim prawny nie zaspo-

L. Wilk [w:] Kodeks karny, op. cit.

M. Kulik, Z prawnokarnej problematyki, op. cit., s. 93.

8 Ibidem.

9 T. Bojarski [w:] Kodeks wykroczeń. Komentarz, red. T. Bojarski, 2016, Legalis. 
kaja społecznego poczucia sprawiedliwości. Mając to na względzie, autor petycji proponuje dodanie art. 288a do Kodeksu karnego, który penalizowałby zachowania polegające na umieszczaniu podpisów, napisów lub rysunków w miejscach do tego niewyznaczonych, których uszkodzenie nie musi powodować naruszenia substancji rzeczy. W propozycji legislacyjnej pojawiają się dotkliwsze sankcje (grzywna, kara ograniczenia wolności albo pozbawianie wolności do lat 5 oraz inne środki karne) niż przewidziane w przepisie 63a k.w. W założeniu autora petycji zabieg ten usprawniłby proces ścigania sprawców nielegalnego graffiti.

\section{Wnioski}

Problem przedstawiony w petycji odnosi się do zjawiska wandalizmu. Warto pochylić się nad postulowaną propozycją zwiększenia skuteczności ścigania i karania sprawców nielegalnego graffiti w taki sposób, aby sankcja była współmierna do wyrządzonej szkody. Autor petycji proponuje dodanie nowego przepisu do Kodeksu karnego, co nie wydaje się najlepszym rozwiązaniem. Skuteczniejsza byłaby modyfikacja już obowiązujących przepisów, które sankcjonują działania polegające na nielegalnym umieszczaniu napisów w miejscach do tego nieprzeznaczonych. Dużo lepszym rozwiązaniem byłoby zaostrzenie sankcji z art. 63a k.w., tak aby przepis spełniał swoją funkcję represyjną. Pożądany cel można osiągnąć także przez dopisanie dodatkowego znamienia do art. 288 k.k. czy 124 k.w., które pozwoliłoby kwalifikować nielegalne graffiti jako czyn wypełniający dyspozycję tych przepisów. Dotychczas nie są one stosowane z uwagi na obowiązującą wykładnię, zgodnie z którą usunięcie napisu lub rysunku umieszczonego w miejscu do tego niewyznaczonym, aby mogło być uznane za przestępstwo z art. 288 k.k. czy wykroczenie z art. 124 k.w., musi naruszać substancję uszkodzonej rzeczy (obecnie graffiti można usunąć w mniej inwazyjny sposób). Ponadto nie zdarza się, aby wykonanie nielegalnego graffiti czyniło daną rzecz niezdatną do używania zgodnie $z$ jej przeznaczeniem (chyba że pokryto nim dzieło sztuki). Warto także zastanowić się, czy uchwała Sądu Najwyższego z 13 marca 1984 r., sygn. akt VI KZP 48/83, stanowiąca wykładnię znamienia „uszkodzenia” rzeczy z art. 288 k.k. i 124 k.w., nie uległa dezaktualizacji w odniesieniu do współczesnych realiów.

\section{Bibliografia}

Bojarski T. [w:] Kodeks wykroczeń. Komentarz, red. T. Bojarski, 2016, Legalis. Gensikowski P. [w:] Kodeks wykroczeń. Komentarz, red. P. Daniluk, 2016, Legalis. Kulik M., Z prawnokarnej problematyki graffiti, „Prokuratura i prawo” 2001, nr 2.

Wilk L. [w:] Kodeks karny. Część szczególna, t. II, Komentarz do artykułów 222-316, red. M. Królikowski, R. Zawłocki, 2017, Legalis. 